\title{
Work Commitment of Secondary School Teachers
}

\author{
S. Sunitha Swarnalatha ${ }^{1} *$
}

\section{ABSTRACT}

Teacher commitment is closely connected to teachers' work performance and their ability to innovate and to integrate new ideas into their own practice, absenteeism, staff turnover, as well as having an important influence on students' achievement in, and attitudes toward school. The present study reveals that majority of teachers had average work commitment levels. The study also reveals that females had better commitment than males. The commitment of experienced teachers was more. The math and science teachers had more commitment than other teachers.

\section{Keywords: Work Commitment, Secondary School, Teachers}

Teachers are our nation builders, the strength of every profession in our country grows out of the knowledge and skills that teachers help to instill in our children. Educators frequently share that teaching is the most difficult job that anyone can have and the most rewarding. Students spend most of their day with teachers, and schools spend most of their money on teachers. Education is a teacher-driven business. Teachers play an important role in educating the future members of society through their work in schools. The quality of education system and the profession of educators within the system depend mainly on teacher who are responsible for guiding, and carrying most of the important tasks and activities in educational institution. Teachers play a significant role in supporting and promoting learning in the class. They are instrumental in transferring learning material to children at their understandable level. Teachers are always under pressure as their accountable to their performance and student performance. Many studies have shown that quality of teachers, their motivation and attitude influence the performance of the students and their academic achievement. For this requires a lot of commitment from the teacher. Commitment means being loyal to ones profession. It requires acquisition of the special knowledge that characterizes a particular profession and application of that knowledge to achieve certain ends. This provides better job security, satisfaction, increases self-esteem and thereby contributes to improve the teachers' commitment. Teacher should have commitment to the teaching profession and should justify public trust and confidence by providing quality education to all students. Maintain membership in some professional

\footnotetext{
${ }^{1}$ Research scholar, Department of Psychology, Osmania university Hyderabad, India

*Responding Author

(C) 2016, S Swarnalatha; licensee IJIP. This is an Open Access Research distributed under the terms of the Creative Commons Attribution License (http://creativecommons.org/licenses/by/2.0), which permits unrestricted use, distribution, and reproduction in any Medium, provided the original work is properly cited.
} 


\section{Work Commitment of Secondary School Teachers}

organizations relevant to his subject and area of specialty. Teacher should be committed to students and maintain professional relations with students. Share responsibilities and prove themselves as successful facilitators of learning for the learners placed under their guidance and supervision. The teacher who is committed to the profession has more efficacy, job satisfaction and high competences. The committed teacher strives more for better performance and keeps abreast with latest technologies which can be useful in class room instruction for teaching learning material

\section{REVIEW OF LITERATURE}

Marridors (2000) stated that the commitment was a deep and profound value of emotional intelligence. It meant aligning with the goals of a group or organization and applying oneself completely for a cause. Simpson and Hood (2000) have however defined commitment in context of the teaching profession. According to them, a committed teacher reflects certain behavioral characteristics. He shows that professional development is a top priority; reflects excitement about teaching and learning; connects with students; show positive attitude about students; is perceptive about student motives, strengths, need and situation. Teaching is a profession that requires personal commitment to maintain enthusiasm for being actively involved in the work (Day, 2004). This concept of commitment as investment of personal resources has long been associated with the professional characteristics of a teacher (Le Compte and Dworkin, 1991). Teacher commitment is thought to be important because it is seen as significant in achieving quality teaching, the ability of teachers to adapt to change, teacher attendance, burnout, staying in the profession, organizational health of the institutional and student attitudes and learning outcomes (Firestone, 1996: Graham, 1996). Teacher commitment may play a vital role in assisting institutions and teachers to adapt to the formidable demands of reframing teaching and learning in institutions for the knowledge society and beyond (Caldwell, 1999). Teaching as profession has undergone some extensive reforms and has been in a state of constant change for over a decade (Sealy, Robson and Hutchins, 1997). Commitment is generally defined as a high level of attachment to an organization, activity or person. Since the late 1950s, interest has been high in the concept of organizational commitment and those factors that promote employee commitment (Tsui and Cheng, 1999).

\section{Objective of the Study:}

1. To study the work commitment of teachers in relation their age, gender, experience, subject expert.

\section{METHODOLOGY}

\section{Locale of study:}

The private high schools teachers of Secunderabad and Hyderabad.

\section{Sample:}

The 150 teachers were selected randomly 


\section{Tools:}

Work Commitment Scale (WCS) - Part II To understand and measure level of principals’ work commitment, a scale developed and standardised by Dr. Imtiaz Nasheed (2000) was used.

WCS is based on dimensions proposed by Meyer and Allen (1991) viz., (i) affective commitment which involves employee's emotional attachment to identification and involvement with organisation, (ii) continuance commitment which refers to commitment based on cost that employees associate with leaving the organisation, and (iii) normative commitment that refers to employee's feeling of obligation to stay with the organisation.

\section{Reliability and Validity of WCS}

Split-half reliability was $r=0.80$ and validity coefficient $r=0.76$ are quite high, hence scale is said to be highly reliable and valid.

\section{Scoring of WCS}

WCS scale consisted of 15 items on the pattern of a Likert type scale having 7-point response category ranging from ' 1 ' strongly disagree to ' 7 ' strongly agree response categories. Higher score indicate committed worker and lower indicated the not committed workers.

\section{RESULTS AND DISCUSSION}

Table 1: Level of work commitment in teacher

\begin{tabular}{|c|c|c|c|}
\hline Dimension & High & Average & Low \\
\hline \multicolumn{4}{|l|}{ Age } \\
\hline \multirow{3}{*}{$\begin{array}{l}\text { 30-40yrs }(\mathrm{N}=36) \\
41-50 \text { yrs }(\mathrm{N}=68) \\
\text { Above 50yrs }(\mathrm{N}=46)\end{array}$} & $8(5.3 \%)$ & $15(10 \%)$ & $13(8.6 \%)$ \\
\hline & $19(12.6 \%)$ & $27(18 \%)$ & $22(14.6 \%)$ \\
\hline & $5(3.33 \%)$ & $21(14 \%)$ & $20(13.3 \%)$ \\
\hline \multicolumn{4}{|l|}{ Gender } \\
\hline \multirow{2}{*}{$\begin{array}{l}\text { Male }(\mathrm{N}=65) \\
\text { Female }(\mathrm{N}=85)\end{array}$} & $4(2.6 \%)$ & $28(18.6 \%)$ & $33(22 \%)$ \\
\hline & $32(21.3 \%)$ & $39(26 \%)$ & $14(9.3 \%)$ \\
\hline \multicolumn{4}{|l|}{ Experience } \\
\hline \multirow{3}{*}{$\begin{array}{l}1 \text {-3yrs }(\mathrm{N}=41) \\
3.1-6 y r s(\mathrm{~N}=37) \\
\text { Above 6yrs }(\mathrm{N}=72)\end{array}$} & $11(7.3 \%)$ & $23(15.3 \%)$ & $7(4.6 \%)$ \\
\hline & $11(7.3 \%)$ & $24(16 \%)$ & $2(1.3 \%)$ \\
\hline & $27(18 \%)$ & $35(23.3 \%)$ & $10(6.6 \%)$ \\
\hline \multicolumn{4}{|l|}{ Subject } \\
\hline \multirow{4}{*}{$\begin{array}{l}\text { Language }(\mathrm{N}=33) \\
\text { Mathematics }(\mathrm{N}=50) \\
\text { Science }(\mathrm{N}=40) \\
\text { Social }(\mathrm{N}=27)\end{array}$} & $13(8.6 \%)$ & 17(11.3\%) & $3(2 \%)$ \\
\hline & $15(10 \%)$ & $33(22 \%)$ & $2(1.3 \%)$ \\
\hline & $12(8 \%)$ & $25(16.6 \%)$ & $7(4.6 \%)$ \\
\hline & $9(6 \%)$ & $11(7.3 \%)$ & $7(4.6 \%)$ \\
\hline
\end{tabular}




\section{Work Commitment of Secondary School Teachers}

Work commitment of secondary school teacher in accordance with age, gender, and experience and subject expertise was presented in the table. The analysis reveals that majority (10\%) of secondary school teachers in age group of 30-40years had average work commitment, only 5.3 percent of them had high work commitment. In age group 41-50years 18\% had average and 14 percent low work commitment. In age group of above 50 years $14 \%$ were average and 13 percent had low work commitment.

It was interesting to note that female teachers 21 percent had high work commitment while only 2 percent of male teachers had high work commitment. Majority of male teachers had low work commitment (22\%). Majority of teachers in three levels of experience had average work commitment.

All most in all subject teachers majority had average work commitment while 10 percent of math teachers high work commitment.

Table 2: Mean differences in work commitment of secondary school teachers according to age, gender, experience and subject expert.

\begin{tabular}{|c|c|c|c|c|}
\hline Dimension & Mean & SD & t/f value & p value \\
\hline \multicolumn{5}{|l|}{ Age } \\
\hline \multirow{3}{*}{$\begin{array}{l}30-40 \mathrm{yrs} \\
41-50 \mathrm{yrs} \\
\text { Above 50yrs }\end{array}$} & 87 & 1.12 & \multirow[t]{3}{*}{127.403} & \multirow[t]{3}{*}{$0.000^{* *}$} \\
\hline & 99 & 0.78 & & \\
\hline & 76 & 0.034 & & \\
\hline \multicolumn{5}{|l|}{ Gender } \\
\hline \multirow{2}{*}{$\begin{array}{l}\text { Male } \\
\text { Female }\end{array}$} & 91 & 111 & \multirow[t]{2}{*}{9.46} & \multirow[t]{2}{*}{$0.03^{*}$} \\
\hline & 0.72 & 0.81 & & \\
\hline \multicolumn{5}{|l|}{ Experience } \\
\hline \multirow{3}{*}{$\begin{array}{l}\text { 1-3yrs } \\
3.1-6 y r s \\
\text { Above 6yrs }\end{array}$} & 83 & 0.72 & \multirow[t]{3}{*}{17.245} & \multirow[t]{3}{*}{$0.001 *$} \\
\hline & 89 & 0.09 & & \\
\hline & 93 & 0.16 & & \\
\hline \multicolumn{5}{|l|}{ Subject } \\
\hline \multirow{4}{*}{$\begin{array}{l}\text { Language } \\
\text { Mathematics } \\
\text { Science } \\
\text { Social }\end{array}$} & 75 & 0.72 & \multirow[t]{4}{*}{19.98} & \multirow[t]{4}{*}{$0.007^{*}$} \\
\hline & 102 & 0.09 & & \\
\hline & 98 & 0.16 & & \\
\hline & 81 & 1.12 & & \\
\hline
\end{tabular}

The mean differences in work commitment in accordance to age, gender, experience and subject expertise was presented in the above table. In the three age group the mean score of 41-50 years was more than the other two age groups, high $f$ value $(\mathrm{f}=127.403)$ indicates a significant difference between the three age groups. The present study concludes that middle age teachers are more committed than old and young teachers. When age is considered, Gerald (2011)

(c) The International Journal of Indian Psychology, ISSN 2348-5396 (e)| ISSN: 2349-3429 (p) | 87 


\section{Work Commitment of Secondary School Teachers}

reported that younger teachers are more committed than older ones. But, Garipağaoğlu (2013) found no significant difference in commitment with regard to age, whereas Hanlon (1983) have reported that older teachers are more committed than younger ones.

From comparing the mean scores of work commitment, the study concludes that female workers are more committed than the males $(\mathrm{p}<0.01)$. The study findings were in tune with findings of (Coladarci, as cited in Chan et al., 2008; Park, 2005) who indicated that females' level of commitment is higher than males' levels of commitment. But, the findings of Borman and Dowling (2008) indicated lower commitment of females. The findings indicate that there is a significant difference in the work commitment of teachers in accordance to the experiences. This finding is also supported by Hung \& Liu (1999) who reported that tenure of teachers is significantly and positively related to commitment level of teachers. The study findings reveal the more experienced are more committed towards their profession. It was interesting to note from the study that mathematics and sciences teachers are more committed than other subject teachers.

\section{CONCLUSION}

The study on work commitment of teachers is important as they play major role in academic performance of students. Those committed to their work have intrinsic drives and aspires toward higher output. Teacher commitment is determinable to school effectiveness and improvement. Teaching is complex and demanding work and there is a daily need for teachers to fully engage in that work with not only their heads, but also their heart. It appears to be a professional necessity for teachers to be emotionally committed to their work, for without this emotional connection teachers face the constant danger of burn-out in an increasingly intensified work environment.

\section{Acknowledgments}

The author appreciates all those who participated in the study and helped to facilitate the research process.

\section{Conflict of Interests}

The author declared no conflict of interests.

\section{REFERENCES}

Borman, G. D., \& Dowling, N. M. (2008). Teacher attrition and retention: A meta-analytic and narrative review of the research. In B. M. Gordon, \& J. E. King, (Eds.), Review of Educational Research, 78(3), 367-404. American Educational Research Association.

Caldwell, B. (1999) The status of new professional in schools of third millennium. Benchmark against the best in medical practices. Paper presented at the international Conference on New Professionalism in teaching, Hong Kong. 


\section{Work Commitment of Secondary School Teachers}

Chan, W. Y, Lau, S, Nie, Y, Lim, S., \& Hogan, D. (2008). Organizational and personal predictors of teacher commitment: The mediating role of teachers' efficacy and identification with school. American Educational Research Journal, 45 (3), 597-630. Retrieved from Academic Source Premier database.

Cochran, L., \& Reese, S. (2007). Preparing the new teacher. Techniques: Connecting Education and Careers, 82(6), 25-27. Retrieved from Academic Source Premier database.

Day,( 2004). A passion for teaching, Routledge Falmer

Firestone, W. A. (1996). Images of teaching and proposals for reform: A comparison of ideas from cognitive and organisational research. Educational Administration Quarterly, 32(2), pp.209-235.

Gerald S. (2011). Rewards and job commitment of primary school teachers in mityana district. Unpublished doctoral dissertation Makerere University, Uganda. Retrieved May 20, 2013 from http://mak.ac.ug/documents/Makfiles/theses/Ssali_Gerald.pdf

Graham, K. C. (1996). Running ahead: Enhancing teacher commitment. Journal of Physical Education, Recreation and Dance, 67(1), pp.45-47.

Gupta, M. \& Gehlawat, M. (2013).A Study of the correlates of organizational commitment among secondary school teachers. Issues and Ideas in Education. 1(2013), 59-71. Retrieved August 26, 2013 from http://iie.chitkara.edu.in/pdf/papers/mar_2013/05_IIE.pdf

Hung, A. \& Liu, J. (1999)Effects of stay-back on teacherse professional commitment. International Journal of Educational Management 13, 5, 226-241

LeCompte, M.D. and Dworkin, A.G. (1991).Giving Up on School, Student Dropouts and Teacher Burnouts. Newbury Park, CA, Corwin Press.

Sealey, R., Robson, M. and Hutchins, T. (1997). "School and University Partnerships: Some findings from a curriculum development project”. Asia Pacific Journal of Teacher Education, 25, 1, 70-89.

Simpson and Hood (2000) Changing Perception and Practice through the Professional Development Model in Belok, Michael and T.E. Deering (Ed.) Teacher Education, Meerut: Anne Books.

Tsui, K. T., \& Cheng, Y. C. (1999). School organizational health and teacher commitment: A contingency study with multi-level analysis. Educational Research and Evaluation, 5, 249-268.

How to cite this article: S Swarnalatha (2016), Work Commitment of Secondary School Teachers, International Journal of Indian Psychology, Volume 3, Issue 4, No. 66, ISSN 23485396 (e), ISSN: 2349-3429 (p), DIP:18.01.163/20160304, ISBN: 978-1-365-39396-9 